"This is an Accepted Manuscript of an article published by Taylor \& Francis in Archives of Physiology and Biochemistry on 18 November 2016, available online:

http://www.tandfonline.com/doi/abs/10.1080/13813455.2016.1248979." 


\title{
PCR arrays indicate that the expression of extracellular matrix and cell adhesion genes in human adipocytes is regulated by IL-1 $\beta$ (interleukin-1 $\beta$ )
}

\author{
Malgorzata A. Kępczyńska ${ }^{1}$, Mohamed S. Zaibi ${ }^{1}$, Suliman Y. Alomar ${ }^{2}$, and Paul Trayhurn ${ }^{1,2,3}$ \\ ${ }^{1}$ Clore Laboratory, University of Buckingham, Buckingham, United Kingdom, ${ }^{2}$ Zoology Department, College \\ of Science, King Saud University, Riyadh, Saudi Arabia, and '3besity Biology Unit, University of Liverpool, \\ Liverpool, United Kingdom
}

RUNNING TITLE: ECM gene expression in human adipocytes

Keywords: Adipose tissue, fibrosis, ICAM1, MMPs, VCAM1

*Correspondence should be addressed to:

Professor Paul Trayburn, FRSE

Clore Laboratory

University of Buckingham

Hunter Street

Buckingham MK18 1EG

$U K$

Email: p.trayhurn@liverpool.ac.uk

Fax: $\quad$ +441280820135 


\begin{abstract}
The role of IL-1 $\beta$ in regulating the expression of extracellular matrix (ECM) and cell adhesion genes in human adipocytes has been examined. Adipocytes differentiated in culture were incubated with IL-1 $\beta$ for 4 or $24 \mathrm{~h}$ and RNA probed with PCR arrays for 84 ECM and cell adhesion genes. Treatment with IL-1 $\beta$ resulted in changes in the expression at one or both time points of $\sim 50 \%$ of the genes probed by the arrays, the majority being down-regulated. Genes whose expression was down-regulated by IL-1 $\beta$ included those encoding several collagen chains and integrin subunits. In contrast, IL-1 $\beta$ induced substantial increases ( $>10$-fold) in the expression of ICAM1, VCAM1, MMP1 and MMP3; the secretion of the encoded proteins was also markedly stimulated. IL-1 $\beta$ has a pervasive effect on the expression of ECM and cell adhesion genes in human adipocytes, consistent with the derangement of tissue structure during inflammation in white fat.
\end{abstract}




\section{Introduction}

The expansion of the adipose tissue depots that defines obesity is associated with the development of several major diseases, particularly type 2 diabetes, the metabolic syndrome and certain cancers (Kopelman, 2000; Rosen \& Spiegelman, 2006; Bluher, 2009). As fat mass expands an inflammatory state is established within white adipose tissue, and this is considered to underpin the development of the obesity-associated disorders (Hotamisligil, 2006; Rosen \& Spiegelman, 2006; Bluher, 2009). This inflammatory condition involves the recruitment of macrophages and other immune cells, as well as the synthesis and release of a series of inflammation-related adipokines from adipocytes and preadipocytes (Weisberg et al., 2003; Xu et al., 2003; Pond, 2005; Bertola et al., 2012). The inflammation-related factors released from fat cells and their precursors encompass a wide range of cytokines and chemokines, including IL-1 $\beta$, IL-6, IL-10, TNF $\alpha$, MCP-1, eotaxin and MCP-4 (Trayhurn, 2005; Meijer et al., 2011; Trayhurn, 2013; Alomar et al., 2015; Alomar et al., 2016).

The extracellular matrix (ECM) is an important component of adipose tissue, providing mechanical support for adipocytes with considerable flexibility and plasticity being required to allow the cells to expand and contract (Mariman \& Wang, 2010; Sun et al., 2013). Fibrosis is evident in adipose tissue depots in obesity and this may reduce the flexibility of the ECM, preventing re-modelling and leading to tissue dysfunction (Halberg et al., 2009; Khan et al., 2009; Kos et al., 2009; Divoux et al., 2010; Mariman \& Wang, 2010; Sun et al., 2013; Hirai et al., 2014). Fibrosis may in part be a consequence of hypoxia in adipose tissue as fat mass expands, and it may also result from local inflammation with the inflammatory state itself being linked to oxygen deprivation (Halberg et al., 2009; Trayhurn, 2013). The expression of specific genes linked to the ECM, such as those encoding the matrix metalloproteinases (MMP) that catalyse the breakdown of specific collagens and other matrix proteins, are strongly upregulated in adipocytes and preadipocytes by inflammatory stimuli (Henegar et al., 2008; O'Hara et al., 2009). In the case of human adipocytes, these stimuli have been shown to include secretions from macrophages and TNF $\alpha$ (O’Hara et al., 2009).

$\mathrm{TNF} \alpha$ is well recognised to have a powerful stimulatory effect on the synthesis and secretion of multiple cytokines and chemokines in human adipocytes, as well as of MMPs (Wang et al., 2005; Cawthorn \& Sethi, 2008). The effect of IL-1 $\beta$ on adipocyte function has, however, received much less attention than TNF $\alpha$ (Bing, 2015), but our recent studies demonstrate that this pro-inflammatory factor stimulates the expression of a number of cytokine and chemokines genes in human adipocytes and preadipocytes, and that the release of the encoded proteins is also stimulated (Alomar et al., 2015; Alomar et al., 2016). In the present study, we have examined 
the effect of IL-1 $\beta$ on the expression of multiple ECM and cell adhesion genes in human adipocytes using a pathway-focused PCR array. The results demonstrate that IL-1 $\beta$ inhibits the expression of a number of ECM and cell adhesion genes within the 'matrisome', particularly those encoding collagen chains and integrin subunits. The results also show that the expression of ICAM1, VCAM1, MMP1 and MMP3, together with the secretion of the proteins encoded by these genes, is strongly stimulated by IL-1 $\beta$.

\section{Materials and methods}

\section{Adipocyte cell culture}

Human fibroblastic preadipocytes (Catalogue \#C-12730, Lot \#400Z008.1) isolated from the subcutaneous adipose tissue of an obese Caucasian female (aged 46 years) were obtained from PromoCell (Germany), together with proprietary culture media. The preadipocytes were plated into 12-well plates $\left(5,000\right.$ cells $\left./ \mathrm{cm}^{2}\right)$ cultured, differentiated into adipocytes and further cultured as described previously (Alomar et al., 2015). In essence, the preadipocytes were taken to confluence in a growth medium containing 5\% foetal calf serum, hydrocortisone $(1 \mu \mathrm{g} / \mathrm{ml})$, epidermal growth factor $(10 \mathrm{ng} / \mathrm{ml})$ and heparin $(90 \mu \mathrm{g} / \mathrm{ml})$. The cells were then transferred for $72 \mathrm{~h}$ to a differentiation medium (without foetal calf serum) containing insulin $(0.5 \mu \mathrm{g} / \mathrm{ml}$ ), thyroxine (9 $\mathrm{ng} / \mathrm{ml})$, dexamethasone (400 $\mathrm{ng} / \mathrm{ml})$, IBMX (44 $\mu \mathrm{g} / \mathrm{ml})$ and ciglitazone $(3 \mu \mathrm{g} / \mathrm{ml})$. The differentiating adipocytes were finally incubated in a nutrition medium containing $3 \%$ foetal calf serum, insulin $(0.5 \mu \mathrm{g} / \mathrm{ml})$ and dexamethasone $(400 \mathrm{ng} / \mathrm{ml})$, with the medium being changed every 2-3 days. The adipocytes were used at 12 days after the induction of differentiation, at which point they contained multiple lipid droplets.

The differentiated adipocytes were incubated with human recombinant IL-1 $\beta$ (Sigma, UK) at a dose of $2 \mathrm{ng} / \mathrm{ml}$, as in previous studies, this giving an approximately maximal response in the expression of those genes investigated earlier (Gao \& Bing, 2011; Alomar et al., 2015); control cells received vehicle. The concentration of IL-1 $\beta$ employed approaches that which may be found locally in tissues during marked inflammation, the intent being to reflect the inflammatory state within adipose tissue in obesity. The cells were incubated with IL-1 $\beta$ for either 4 or $24 \mathrm{~h}$, to enable both acute and chronic responses to be assessed. At the end of the incubation period, the medium was removed and stored at $-20^{\circ} \mathrm{C}$, and the adipocytes washed, frozen in TRI Reagent (Sigma, UK) and stored at $-80^{\circ} \mathrm{C}$, as previously (Alomar et al., 2015). A total of six sets of cells was taken for each experimental group. 


\section{RNA extraction and PCR arrays}

Total RNA was extracted and PCR arrays performed essentially as previously described (Alomar et al., 2015). In outline, the adipocytes were homogenised in the TRI Reagent in which they had been stored and total RNA extracted using an RNeasy Micro Kit (Qiagen, UK). The purity of the extracted RNA was close to 2.0 , based on the $260 / 280 \mathrm{~nm}$ and $260 / 230 \mathrm{~nm}$ ratios (NanoDrop 1000; Wilmington, USA), and the RNA Integrity Number (Agilent 2100 Bioanalyser; Agilent Technologies, Germany) was approximately 10.

The extracted RNA was DNAse-treated, reverse transcribed using a RT $^{2}$ First Strand Kit (Qiagen, UK) and screened with a $\mathrm{RT}^{2}$ Profiler PCR array for 84 Human Extracellular Matrix and Cell Adhesion genes (Qiagen, UK). PCR amplification was performed by real-time PCR detection (ABI StepOneplus; Applied Biosystems, USA) with two step thermal cycling; $95^{\circ} \mathrm{C}$ for $10 \mathrm{~min}$, and then 40 cycles of $95^{\circ} \mathrm{C}$ for $15 \mathrm{sec}$ and $60^{\circ} \mathrm{C}$ for $1 \mathrm{~min}$, as previously (Alomar et al., 2015). The data were analysed by the comparative $2^{-\Delta \Delta}$ Ct method (Livak \& Schmittgen, 2001) and expressed as fold-charges in the target gene normalised to the reference genes ( $A C T B, B 2 M$, GAPDH, HPRT, RLPO) for the IL-1 $\beta$ treated adipocytes and related to the expression level of the untreated control cells, according to the manufaturer's protocol. In outline, the $\Delta \mathrm{Ct}$ for each gene of interest (GOI) in each plate was calculated using the Ct values for the gene and the housekeeping genes (HKG) used for normalization: $\Delta \mathrm{Ct}=\mathrm{Ct}$ GOI $-\mathrm{Ct}$ average HKG. Multiple HKGs help ensure that errors are not introduced through variations between treatment groups in the expression level of a specific HKG.

The manufacturer states that the PCR array system demonstrates strong correlations across technical replicates, lots and instruments with average correlation coefficients $>0.99$.

\section{Protein measurements}

The release into the medium of ICAM1, VCAM1, MMP1 and MMP3 was measured using MSD immunoassays (Meso Scale Discovery, USA); the media were centrifuged prior to analysis to remove any cell debris. These immunoassays provide a rapid, sensitive measurement of specific proteins in small sample volumes. Plates were pre-coated with antibodies on independent, discrete spots and the assay then performed essentially according to the manufacturer's instructions, as described previously (Alomar et al., 2015; Alomar et al., 2016). The data was analysed using Proprietary Meso Scale software; the lowest level of detection was $1.03 \mathrm{pg} / \mathrm{ml}$ for ICAM1 (interlot CV 17.8\%), $6 \mathrm{pg} / \mathrm{ml}$ for VCAM1 (interlot CV 2.6\%), $11 \mathrm{pg} / \mathrm{ml}$ for MMP1 and $2.1 \mathrm{pg} / \mathrm{ml}$ for MMP3 (mean intraplate $\mathrm{CV}<15 \%$ for both MMP1 and MMP3). 


\section{Statistical analysis}

The statistical significance of differences between the IL-1 $\beta$ treated and control groups was assessed with Student's $t$ test; a value of $P<0.05$ was taken as being statistically significant.

\section{Results}

\section{Gene expression: PCR arrays}

The present study was conducted on human adipocytes taken 12 days after the induction of differentiation from preadipocytes, at which point they exhibit multiple lipid droplets in the cytoplasm with validation studies indicating that marker genes characteristic of differentiated fat cells are expressed. The cells were treated with IL-1 $\beta$ for 4 or $24 \mathrm{~h}$ at a dose which induces a maximal response in the expression of selected genes in adipocytes (Gao \& Bing, 2011; Alomar et al., 2015). The possibility cannot be excluded, however, that not all genes whose expression is modulated by IL-1 $\beta$ will be maximally effected by the dose used. A focused pathway-specific PCR array was used to probe the expression of a panel of 84 genes encoding proteins linked to the ECM and cell adhesion. A stringent criterion of $>2$-fold difference in mRNA level, with $P<0.05$ or greater, between treated and control cells was used to assess whether treatment with IL-1 $\beta$ resulted in differential expression of a gene.

The expression at $4 \mathrm{~h}$ of four of the genes on the arrays was increased $>10$-fold in response to IL-1 $\beta$, the greatest increase being for ICAM1 (Figure 1); the ICAM1 mRNA level was $>200$-fold higher in the treated cells than in the control adipocytes. The other three genes which exhibited large increase in mRNA level on treatment with IL-1 $\beta$ were VCAM1, MMP1 and $M M P 3$, the level at $4 \mathrm{~h}$ being 22-fold, 13-fold and 12.5-fold higher, respectively, than in the controls. The mRNA level was also increased at $24 \mathrm{~h}$ in the treated cells, but the elevation was much lower at this time-point than at $4 \mathrm{~h}$ for each of the four genes (Figure 1). The expression of five further genes - TNC, HAS1, LAMB3, THBS1 and TIMP1 - was also stimulated at both 4 and $24 \mathrm{~h}$ (Table 1), but the increases in mRNA level were smaller, varying from 2- to 8-fold relative to the controls. In contrast to the other genes, the response to IL-1 $\beta$ was higher, rather than lower, at $24 \mathrm{~h}$ than at $4 \mathrm{~h}$ for HAS1, THBS1 and TIMP1.

The expression of both SELE and CD44 was increased at $4 \mathrm{~h}$, but not at $24 \mathrm{~h}$, while MMP9, THBS2 and COL7A1 were up-regulated only at $24 \mathrm{~h}$. The expression of three genes TGFB1, CTGF and SPP1 (which encodes the pro-inflammatory mediator osteopontin) - was down-regulated in response to IL-1 $\beta$ at both 4 and $24 \mathrm{~h}$, while that of two genes - ITGB5 and ADAMTS1 - was decreased only at $4 \mathrm{~h}$. The full list of genes whose expression was significantly 
altered by treatment with IL-1 $\beta$, together with the names of the encoded proteins, is shown in Table 1.

The expression of as many as 22 genes ( $>25 \%$ of the probes on the arrays) was downregulated at $24 \mathrm{~h}$ (Table 1), these including several genes encoding collagen chains (COL1A1, COL5A1, COL6A1, COL11A1, COL14A1, COL15A1), matrix metalloproteinases (MMP7, MMP11, MMP16) and integrin subunits (ITGA3, ITGB3, ITGA6, ITGA4). The genes that were most strongly down-regulated by IL-1 $\beta$ at $24 \mathrm{~h}$ were an integrin (ITGA4), a collagen (COL14A1) and a matrix metalloproteinase (MMP16), the mRNA level of each of which was reduced by $>5$ fold (Figure 2).

\section{Protein secretion}

The culture media were examined to determine whether the changes induced by IL-1 $\beta$ in the expression of key genes, as indicated by the PCR arrays, were mirrored in the amount of the encoded protein released by the adipocytes. ICAM1, VCAM1, MMP1 and MMP3 were analysed since at the gene expression level they showed the most substantial responses to IL- $1 \beta$. Figure 3 shows the amount of each of these proteins in the medium at 4 and $24 \mathrm{~h}$; greater quantities were found at $24 \mathrm{~h}$, reflecting the accumulation with time of the secreted protein. In addition, the consequences of the lag between the expression of a gene and the subsequent synthesis and release of the protein product will be much more evident at shorter time points.

Each of the four proteins analysed was readily detected in the medium at 4 and $24 \mathrm{~h}$, and treatment with IL-1 $\beta$ resulted in an increase in the amount released at both times. However, the stimulatory effect of IL-1 $\beta$ was more evident at $24 \mathrm{~h}$ with the amount of ICAM1 being 56 -fold higher at this time point than in the controls. The increase in VCAM1 at $24 \mathrm{~h}$ in response to IL$1 \beta$ was 3.5-fold, while for MMP1 and MMP3 it was 7.8- and 18-fold, respectively.

\section{Discussion}

The present study employing focused PCR pathway arrays demonstrates that the expression of multiple genes encoding proteins associated with the ECM and cell adhesion is modulated by the classical pro-inflammatory cytokine IL-1 $\beta$. PCR arrays provide a valuable tool for determining expression in that a number of genes in a given pathway can be assessed simultaneously with the quantitative precision of real-time PCR. Of the 84 genes on the arrays employed here, the expression of almost half (41) was altered in response to IL-1 $\beta$, either at both 4 and $24 \mathrm{~h}$, or at one of these two times. Changes in expression at both time points implies a direct regulatory effect of IL-1 $\beta$. Alteration at $24 \mathrm{~h}$, even without any change at $4 \mathrm{~h}$, is also likely to be of significance in terms of the structure and re-modelling of the ECM. 
Of the genes whose expression was altered by IL-1 $\beta$, the majority (66\%) were downregulated. The most strongly up-regulated included two matrix metalloproteinase genes, MMP1 and $M M P 3$, and the secretion of their encoded proteins was also stimulated by IL-1 $\beta$. The MMPs as a group are endopeptidases which play an important role in degrading the proteins of the ECM (Mariman \& Wang, 2010), including collagens, with MMP1 being an interstitial collagenase and MMP3 a stromelysin (stromelysin-1); their up-regulation by IL-1 $\beta$ is indicative of an inflammation-induced stimulation of the remodelling of the ECM. Previous studies have demonstrated that MMP1 and MMP3 are secreted from human adipocytes (Traurig et al., 2006; van Beek et al., 2008; Mariman \& Wang, 2010), expression and secretion being stimulated by factors released by macrophages and specifically by TNF $\alpha$ (O’Hara et al., 2009).

IL-1 $\beta$ has been shown to stimulate the expression and secretion of MMP1 and MMP3 in other cell types, including human preadipocytes (Domeij et al., 2002; Liacini et al., 2005; Gao \& Bing, 2011). In the present study, another MMP, MMP9 (also known as gelatinase B), was upregulated by IL-1 $\beta$ only at $24 \mathrm{~h}$ and the increase in mRNA was modest. MMP9 expression has previously been shown to be strongly up-regulated in human adipocytes exposed to macrophageconditioned media (O'Hara et al., 2009), and the much more modest effect observed here with IL-1 $\beta$ alone suggests that other factors released by macrophages (such as TNF $\alpha$ ) are important in stimulating the expression of this gene.

The two most highly up-regulated genes in response to IL-1 $\beta$ were ICAM1 and VCAM1, and again this was evident at both the level of expression and in the secretion of the protein product. ICAM1 was particularly sensitive to IL-1 $\beta$, and the expression of both cellular adhesion molecules is well recognised to be highly inducible by this cytokine, as well as by TNF $\alpha$, in other cell types (Collie-Duguid \& Wahle, 1996; Haraldsen et al., 1996; Tessier et al., 1996). There was a substantial, but transient stimulation (at $4 \mathrm{~h}$ only), of the expression of SELE, a gene that codes for the cell adhesion molecule selectin-E, which plays a role in inflammation. The expression of $L A M B 3$, a laminin subunit gene, was stimulated by IL-1 $\beta$ (at 4 and $24 \mathrm{~h}$ ), but the expression of the other two genes on the arrays associated with laminin sub-units, $L A M C 1$ and $L A M A 2$, was inhibited (at 24 h), the laminins being ECM glycoproteins (Mariman \& Wang, 2010).

Similarly, while the expression of COL7A1, which encodes collagen type VII alpha 1, was slightly stimulated by IL-1 $\beta$ at $24 \mathrm{~h}$, the expression of six other genes for collagens was downregulated at $24 \mathrm{~h}$. Thus a key effect of IL-1 $\beta$ was to inhibit the expression of a series of genes encoding collagen chains, thereby comprising matrix re-modelling and tissue structure. In addition, the expression of all five integrin genes present on the arrays was suppressed by IL- $1 \beta$, at $4 \mathrm{~h}$ in the case of ITGB5 and at $24 \mathrm{~h}$ for the others. This inhibition would be expected to 
reduce cell adhesion to the ECM. It is noteworthy that despite the strong stimulation of the expression of MMP1 and MMP3, the expression of three other MMP genes, MMP7, MMP11 and MMP16, was reduced by IL-1 $\beta$ at $24 \mathrm{~h}$; indeed, MMP16 was the most strongly down-regulated gene measured by the arrays.

MMP7, which is also known as matrilysin or PUMP-1, is a membrane-bound protease, as is MM16, which degrades specific collagens and fibronectin (Mariman \& Wang, 2010). MM11, known as stromelysin 3, is, however, not membrane-bound. MMP11 expression in human adipocytes was previously found to be stimulated on exposure to macrophage-conditioned medium, as was that of a number of other MMP genes in addition to MMP1 and MMP3 (O'Hara et al., 2009). Since in the present study, IL-1 $\beta$ inhibited MMP11 expression, other factors released from activated macrophages must counteract the inhibitory effect of this cytokine, and the potential candidates include TNF $\alpha$. There is evidence that MMP11 is a potent negative regulator of adipogenesis (Andarawewa et al., 2005).

A differential effect of IL-1 $\beta$ on the expression of closely linked genes was also evident with the TIMPs (tissue inhibitor of metalloproteinases). There was a small increase in the expression of TIMP1 (at 4 and 24 h), while both TIMP2 and TIMP3 expression decreased (at 24 h). Overall, the balance of effects of IL-1 $\beta$ in human adipocytes would appear to favour the stimulation of the synthesis and release of the major matrix metalloproteinases (MMP1 and MMP3) while decreasing the production of key inhibitors of these enzymes.

Remodelling of the ECM is evident during the expansion of adipose tissue and fibrosis is a hallmark of the tissue in obesity (Halberg et al., 2009; Khan et al., 2009; Mariman \& Wang, 2010). Inflammation may underlie both ECM remodelling and the development of fibrosis, and the strong stimulation of MMP1 and MMP3 synthesis and release by adipocytes in response to IL-1 $\beta$ is consistent with the important role that these enzymes have been shown to play in modifying the structure of the matrix, including in obese white fat (Chakraborti et al., 2003; Chavey et al., 2003). IL-1 $\beta$ may be primarily derived from activated macrophages within adipose tissue, but it can also be released from other cells in the tissue, including the adipocytes themselves which would imply an autocrine or paracrine action. Macrophages, adipocytes and preadipocytes each synthesis and release IL-1 $\beta$, and production is increased in an inflammatory state (see Fain, 2006; Alomar et al., 2015).

It should be noted that the adipocytes used in the present work were differentiated from the preadipocytes of a single lean donor and this is a limitation of the study. The responsiveness to IL-1 $\beta$ may vary between individuals, particularly in terms of the scale of response of specific genes or in the relative response between different genes. Neverthless, in our previous and 
ongoing studies we have observed a general consistency of responsiveness in human adipocytes to inflammatory stimuli independent of the donor.

\section{Conclusions}

The pro-inflammatory cytokine IL-1 $\beta$ has a pervasive effect on the expression by human adipocytes of genes encoding key proteins involved in the ECM and cell adhesion. There is a marked down-regulation of the expression of genes for a number of different collagen chains and integrin subunits. On the other hand, the expression and release of the major MMPs, MMP1 and MMP3, is strongly stimulated, and this is also the case for two key cellular adhesion molecules, ICAM1 and VCAM1. The ECM in white adipose tissue is required to be highly flexible in order to accommodate the expansion and/or contraction of the adipocytes, as well as changes in the shape and size of preadipocytes as they differentiate into mature fat cells. There is also considerable variability in the size of adipocytes within a fat depot, and again this requires plasticity in the ECM. Inflammation, through the mediation of IL-1 $\beta$ as well as of TNF $\alpha$ and other factors, plays a major role in the modelling and function of the ECM in white adipose tissue, and underpins the dysfunction and metabolic derangements that characterises the tissue in obesity.

\section{Declaration of interest}

The authors are grateful to the Distinguished Scientist Fellowship Programme at King Saud University for financial support of this work. The authors declare that they have no conflicts of interest in regard to this study. 


\section{References}

Alomar SY, Zaibi MS, Kępczyńska MA, Gentili A, Alkhuriji A, Mansour L, Dar JA, Trayhurn P. (2015). PCR array and protein array studies demonstrate that IL-1 $\beta$ (interleukin-1 $\beta$ ) stimulates the expression and secretion of multiple cytokines and chemokines in human adipocytes. Arch Physiol Biochem 121:187-93.

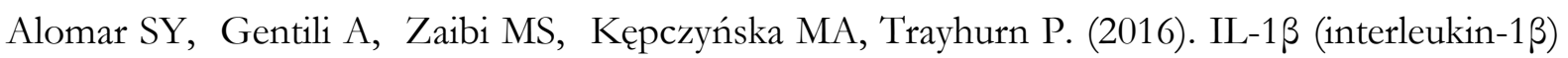
stimulates the production and release of multiple cytokines and chemokines by human preadipocytes. Arch Physiol Biochem 122:117-22.

Andarawewa KL, Motrescu ER, Chenard MP, Gansmuller A, Stoll I, Tomasetto C, Rio MC. (2005). Stromelysin-3 is a potent negative regulator of adipogenesis participating to cancer cell-adipocyte interaction/crosstalk at the tumor invasive front. Cancer Res 65:10862-71.

Bertola A, Ciucci T, Rousseau D, Bourlier V, Duffaut C, Bonnafous S, Blin-Wakkach C, Anty R, Iannelli A, Gugenheim J, Tran A, Bouloumié A, Gual P, Wakkach A. (2012). Identification of adipose tissue dendritic cells correlated with obesity-associated insulinresistance and inducing Th17 responses in mice and patients. Diabetes 61:2238-47.

Bing C. (2015). Is interleukin-1 $\beta$ a culprit in macrophage-adipocyte crosstalk in obesity? Adipocyte 4:149-52.

Blüher M. (2009). Adipose tissue dysfunction in obesity. Exp Clin Endocrinol Diabetes 117:241-50.

Cawthorn WP, Sethi JK. (2008). TNF- $\alpha$ and adipocyte biology. FEBS Lett 582:117-31.

Chakraborti S, Mandal M, Das S, Mandal A, Chakraborti T. (2003). Regulation of matrix metalloproteinases: an overview. Mol Cell Biochem 253:269-85.

Chavey C, Mari B, Monthouel MN, Bonnafous S, Anglard P, Van Obberghen E, TartareDeckert S. (2003). Matrix metalloproteinases are differentially expressed in adipose tissue during obesity and modulate adipocyte differentiation. J Biol Chem 278:11888-96.

Collie-Duguid ES, Wahle KW. (1996). Inhibitory effect of fish oil N-3 polyunsaturated fatty acids on the expression of endothelial cell adhesion molecules. Biochem Biophys Res Commun 220:969-74.

Divoux A, Tordjman J, Lacasa D, Veyrie N, Hugol D, Aissat A, Basdevant A, Guerre-Millo M, Poitou C, Zucker J-D, Bedossa P, Clément K. (2010). Fibrosis in human adipose tissue: composition, distribution, and link with lipid metabolism and fat mass loss. Diabetes 59:2817-25.

Domeij H, Yucel-Lindberg T, Modeer T. (2002). Signal pathways involved in the production of MMP-1 and MMP-3 in human gingival fibroblasts. Eur J Oral Sci 110:302-6. 
Fain JN. (2006). Release of interleukins and other inflammatory cytokines by human adipose tissue is enhanced in obesity and primarily due to the nonfat cells. Vitam Horm 74:443-77.

Gao D, Bing C. (2011). Macrophage-induced expression and release of matrix metalloproteinase 1 and 3 by human preadipocytes is mediated by IL- $1 \beta$ via activation of MAPK signaling. $J$ Cell Physiol 226:2869-80.

Halberg N, Khan T, Trujillo ME, Wernstedt-Asterholm I, Attie AD, Sherwani S, Wang ZV, Landskroner-Eiger S, Dineen S, Magalang UJ, Brekken RA, Scherer PE. (2009). Hypoxia-inducible factor $1 \alpha$ induces fibrosis and insulin resistance in white adipose tissue. Mol Cell Biol 29:4467-83.

Haraldsen G, Kvale D, Lien B, Farstad IN, Brandtzaeg P. (1996). Cytokine-regulated expression of E-selectin, intercellular adhesion molecule-1 (ICAM-1), and vascular cell adhesion molecule-1 (VCAM-1) in human microvascular endothelial cells. I Immunol 156:2558-65.

Henegar C, Tordjman J, Achard V, Lacasa D, Cremer I, Guerre-Millo M, Poitou C, Basdevant A, Stich V, Viguerie N, Langin D, Bedossa P, Zucker JD, Clément K. (2008). Adipose tissue transcriptomic signature highlights the pathological relevance of extracellular matrix in human obesity. Genome Biol 9:R14 doi: 10.1186/gb-2008-9-1-r14.

Hirai S, Ohyane C, Kim Y-I, Lin S, Goto T, Takahashi N, Kim C-S, Kang J, Yu R, Kawada T. (2014). Involvement of mast cells in adipose tissue fibrosis. Am J Physiol Endocrinol Metab 306:E247-55.

Hotamisligil GS. (2006). Inflammation and metabolic disorders. Nature 444:860-67.

Khan T, Muise ES, Iyengar P, Wang ZV, Chandalia M, Abate N, Zhang BB, Bonaldo P, Chua S, Scherer PE. (2009). Metabolic dysregulation and adipose tissue fibrosis: role of collagen VI. Mol Cell Biol 29:1575-91.

Kopelman PG. (2000). Obesity as a medical problem. Nature 404:635-43.

Kos K, Wong S, Tan B, Gummesson A, Jernas M, Franck N, Kerrigan D, Nystrom FH, Carlsson LMS, Randeva HS, Pinkney JH, Wilding JPH. (2009). Regulation of the fibrosis and angiogenesis promoter SPARC/osteonectin in human adipose tissue by weight change, leptin, insulin, and glucose. Diabetes 58:1780-88.

Liacini A, Sylvester J, Li WQ, Zafarullah M. (2005). Mithramycin downregulates proinflammatory cytokine-induced matrix metalloproteinase gene expression in articular chondrocytes. Arthritis Res Ther 7:R777-83.

Livak KJ, Schmittgen TD. (2001). Analysis of relative gene expression data using real-time quantitative PCR and the $2\left({ }^{\Delta \Delta} \mathrm{C}_{\mathrm{T}}\right)$ method. Methods 25:402-8. 
Mariman EC, Wang P. (2010). Adipocyte extracellular matrix composition, dynamics and role in obesity. Cell Mol Life Sci 67:1277-92.

Meijer K, de Vries M, Al-Lahham S, Bruinenberg M, Weening D, Dijkstra M, Kloosterhuis N, van der Leij RJ, van der Want H, Kroesen BJ, Vonk R, Rezaee F. (2011). Human primary adipocytes exhibit immune cell function: adipocytes prime inflammation independent of macrophages. PLoS One 6:e17154.

O’Hara A, Lim F-L, Mazzatti D, Trayhurn P. (2009). Microarray analysis identifies matrix metalloproteinases (MMPs) as key genes whose expression is up-regulated in human adipocytes by macrophage-conditioned medium. Pflügers Archiv Eur J Physiol 458:1103-14.

Pond CM. (2005). Adipose tissue and the immune system. Prost Leuk. Essen Fatty Acids 73:17-30.

Rosen ED, Spiegelman BM. (2006). Adipocytes as regulators of energy balance and glucose homeostasis. Nature 444:847-53.

Sun K, Tordjman J, Clément K, Scherer PE. (2013). Fibrosis and adipose tissue dysfunction. Cell Metab 18:470-7.

Tessier PA, Cattaruzzi P, McColl SR. (1996). Inhibition of lymphocyte adhesion to cytokineactivated synovial fibroblasts by glucocorticoids involves the attenuation of vascular cell adhesion molecule 1 and intercellular adhesion molecule 1 gene expression. Arthritis Rheum 39:226-34.

Traurig MT, Permana PA, Nair S, Kobes S, Bogardus C, Baier LJ. (2006). Differential expression of matrix metalloproteinase 3 (MMP3) in preadipocytes/stromal vascular cells from nonobese nondiabetic versus obese nondiabetic Pima Indians. Diabetes 55:3160-5.

Trayhurn P. (2005). Endocrine and signalling role of adipose tissue: new perspectives on fat. Acta Physiol Scand 184:285-93.

Trayhurn P. (2013). Hypoxia and adipose tissue function and dysfunction in obesity. Physiol Rev $93: 1-21$

van Beek EA, Bakker AH, Kruyt PM, Vink C, Saris WH, Franssen-van Hal NLW, Keijer J. (2008). Comparative expression analysis of isolated human adipocytes and the human adipose cell lines LiSa-2 and PAZ6. Int J Obes 32:912-21.

Wang B, Jenkins JR, Trayhurn P. (2005). Expression and secretion of inflammation-related adipokines by human adipocytes differentiated in culture: Integrated response to TNF- $\alpha$. Am J Physiol Endocrinol Metab 288:E731-E40.

Weisberg SP, McCann D, Desai M, Rosenbaum M, Leibel RL, Ferrante AW, Jr. (2003). Obesity is associated with macrophage accumulation in adipose tissue. J Clin Invest 112:1796-808. 
Xu H, Barnes GT, Yang Q, Tan G, Yang D, Chou CJ, Sole J, Nichols A, Ross JS, Tartaglia LA, Chen H. (2003). Chronic inflammation in fat plays a crucial role in the development of obesity-related insulin resistance. J Clin Invest 112:1821-30. 
Table 1. Genes probed by extracellular matrix and cell adhesion PCR pathway arrays where expression was up- or down-regulated in human white adipocytes by treatment with IL-1 $\beta$

\begin{tabular}{|c|c|c|c|}
\hline Gene & Encoded protein & $\begin{array}{c}\text { Fold change at } \\
4 \mathrm{~h} \text { with IL-1 } \beta\end{array}$ & $\begin{array}{l}\text { Fold change at } \\
24 \mathrm{~h} \text { with IL-1 } \beta\end{array}$ \\
\hline \multicolumn{4}{|c|}{ Upregulated: 4 and $24 \mathrm{~h}$} \\
\hline ICAM1 & Intercellular adhesion molecule-1 & 213.4 & 27.5 \\
\hline$V C A M 1$ & Vascular cell adhesion molecule-1 & 22.3 & 2.32 \\
\hline MMP1 & Matrixmetalloproteinase-1 & 13.0 & 8.60 \\
\hline$\overline{M M P 3}$ & Matrix metalloproteinase-3 & 12.6 & 12.2 \\
\hline TNC & Tenascin C & 7.95 & 4.79 \\
\hline HAS1 & Hyaluronan synthase-1 & 4.95 & 5.42 \\
\hline$L A M B 3$ & Laminin subunit beta-3 & 3.98 & $2.33^{*}$ \\
\hline THBS1 & Thrombospondin-1 & 2.14 & 3.01 \\
\hline TIMP1 & $\begin{array}{l}\text { Tissue inhibitor of } \\
\text { metalloproteinases-1 }\end{array}$ & 2.08 & 3.02 \\
\hline \multicolumn{4}{|c|}{ Upregulated: 4 h only } \\
\hline SELE & Selectin E & 17.2 & \\
\hline CD44 & CD44 antigen & 3.97 & \\
\hline \multicolumn{4}{|c|}{ Upregulated: 24 h only } \\
\hline MMP9 & Matrix metalloproteinase-9 & & 2.80 \\
\hline THBS2 & Thrombospondin-2 & & 2.47 \\
\hline COL7A1 & Collagen type VII alpha1 & & 2.10 \\
\hline \multicolumn{4}{|c|}{ Downregulated: 4 and $24 \mathrm{~h}$} \\
\hline TGFB1 & Transforming growth factor beta-1 & 0.475 & 0.283 \\
\hline CTGF & Connective tissue growth factor & 0.392 & 0.358 \\
\hline SPP1 & Secreted phosphoprotein-1 & $0.333^{*}$ & 0.237 \\
\hline \multicolumn{4}{|c|}{ Downregulated: 4 h only } \\
\hline ITGB5 & Integrin subunit beta-5 & 0.446 & \\
\hline ADAMTS1 & $\begin{array}{l}\text { A disintegrin-like and } \\
\text { metalloprotease with } \\
\text { thrombospondin type } 1 \text { motif } 1\end{array}$ & 0.295 & \\
\hline \multicolumn{4}{|c|}{ Downregulated: 24 h only } \\
\hline ECM1 & Extracellular matrix protein-1 & & 0.500 \\
\hline CTNND2 & Catenin delta-2 & & $0.487^{*}$ \\
\hline$L A M C 1$ & Laminin subunit gamma-1 & & 0.459 \\
\hline COL5A1 & Collagen type $\mathrm{V}$ alpha-1 & & 0.449 \\
\hline$I T G A 6$ & Integrin subunit alpha-6 & & 0.445 \\
\hline COL6A1 & Collagen type V1 alpha-1 & & 0.439 \\
\hline TIMP2 & $\begin{array}{l}\text { Tissue inhibitor of } \\
\text { metalloproteinases } 2\end{array}$ & & 0.437 \\
\hline$I T G A 3$ & Integrin subunit alpha-3 & & $0.436^{*}$ \\
\hline
\end{tabular}




\begin{tabular}{|l|l|c|c|}
\hline SPARC & $\begin{array}{l}\text { Secreted protein acidic and cysteine } \\
\text { rich (osteonectin) }\end{array}$ & 0.435 \\
\hline MMP7 & Matrix metalloproteinase-7 & & 0.412 \\
\hline COL15A1 & Collagen type XV alpha-1 & & 0.407 \\
\hline COL1A1 & Collagen type I alpha-1 & & 0.387 \\
\hline MMP11 & Matrix metalloproteinase-11 & & 0.359 \\
\hline CLEC3B & $\begin{array}{l}\text { C-Type lectin domain family 3 } \\
\text { member B (tetranectin) }\end{array}$ & & 0.356 \\
\hline ITGB3 & Integrin subunit beta-3 & & 0.346 \\
\hline LAMA2 & Laminin subunit alpha-2 & & 0.317 \\
\hline TIMP3 & Tissue inhibitor of \\
metalloproteinases-3 & & 0.317 \\
\hline CNTN1 & Contactin-1 & & 0.210 \\
\hline COL11A1 & Collagen type XI alpha-1 & & 0.200 \\
\hline ITGA4 & Integrin subunit alpha-4 & & 0.185 \\
\hline COL14A1 & Collagen type XIV alpha-1 & & 0.156 \\
\hline MMP16 & Matrix metalloproteinase-16 & & 0.127 \\
\hline & & & \\
\hline
\end{tabular}

Human adipocytes were incubated in the presence or absence of human recombinant IL-1 $\beta$ (2 $\mathrm{ng} / \mathrm{ml}$ ) for 4 or $24 \mathrm{~h}$. The expression of ECM and cell adhesion genes was probed using PCR pathway arrays. The genes listed are those where there was a change in mRNA level of at least 2fold which was statistically significant $(P<0.05$ or more). The results are expressed as fold-changes for the IL-1 $\beta$ treated adipocytes relative to the untreated controls, and are the means of 5-6 independent sets of adipocytes at both time points; all differences shown are significant at $P<0.001$ or better, except those marked * where $P<0.05$. 


\section{Legends to Figures}

\section{Figure 1}

Stimulatory effect of IL-1 $\beta$ on the expression of extracellular matrix and cell adhesion genes in human adipocytes. The adipocytes were incubated with IL-1 $\beta(2 \mathrm{ng} / \mathrm{ml})$ for either 4 or $24 \mathrm{~h}$. The four most highly up-regulated genes are shown: ICAM1, VCAM1, MMP1 and MMP3. The results, which are expressed as fold-changes in the cells treated with IL-1 $\beta$ relative to the control cells, are means \pm SE (bars) for 5-6 independent sets of adipocytes. ${ }^{* * *} P<0.001$ compared with the control cells at the same time point.

\section{Figure 2}

Inhibitory effect of IL-1 $\beta$ on the expression of extracellular matrix and cell adhesion genes in human adipocytes. The adipocytes were incubated with IL-1 $\beta(2 \mathrm{ng} / \mathrm{ml})$ for either 4 or $24 \mathrm{~h}$. The four most highly down-regulation genes are shown: COL11A1, ITGA4, COL14A1 and MMP16. The results, which are expressed as fold-changes in the cells treated with IL-1 $\beta$ relative to the control cells, are means $\pm \mathrm{SE}$ (bars) for 5-6 independent sets of adipocytes. $* P<0.05$, $* * * P<0.001$ compared with the control cells at the same time point.

\section{Figure 3}

Stimulatory effect of IL-1 $\beta$ on the secretion of extracellular matrix proteins by human adipocytes. The adipocytes were incubated with IL-1 $\beta(2 \mathrm{ng} / \mathrm{ml})$ for either 4 or $24 \mathrm{~h}$, and proteins were measured that were encoded by the genes which exhibited the strongest response to IL-1 $\beta$. The results are means \pm SE (bars) for 5-6 independent sets of adipocytes. $* P<0.05$, $* * * P<0.001$ compared with the control cells at the same time point. 
Figure 1

ICAM1

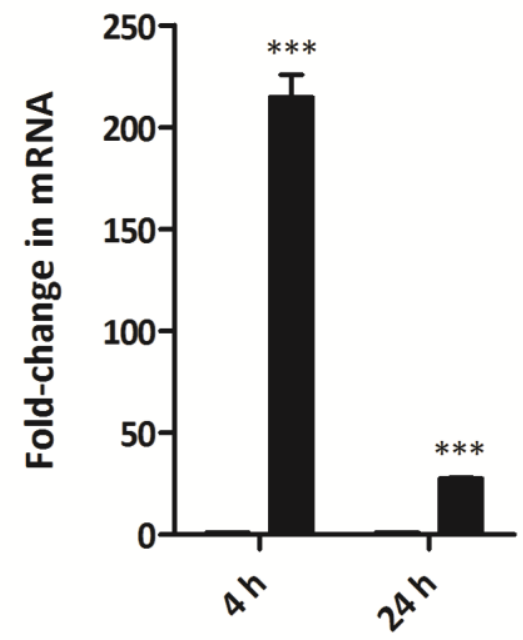

Incubation time

MMP-1

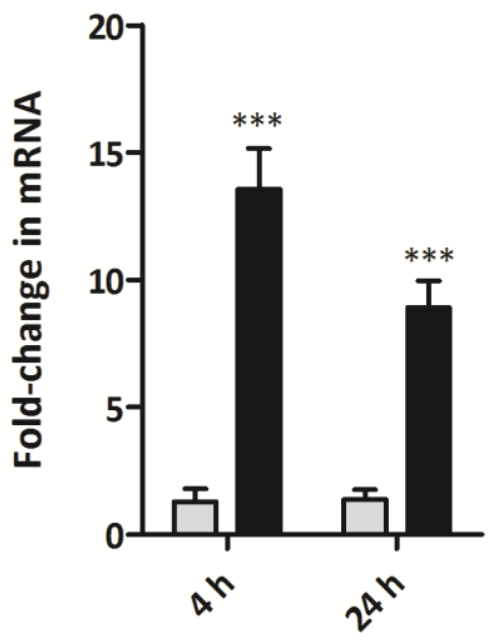

Incubation time
VCAM1

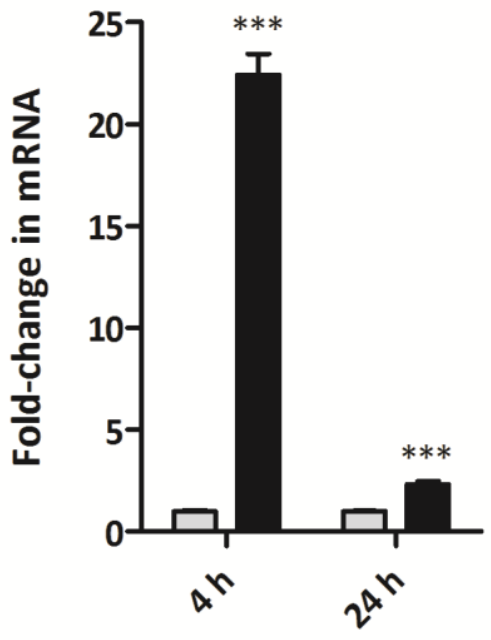

Incubation time

MMP-3

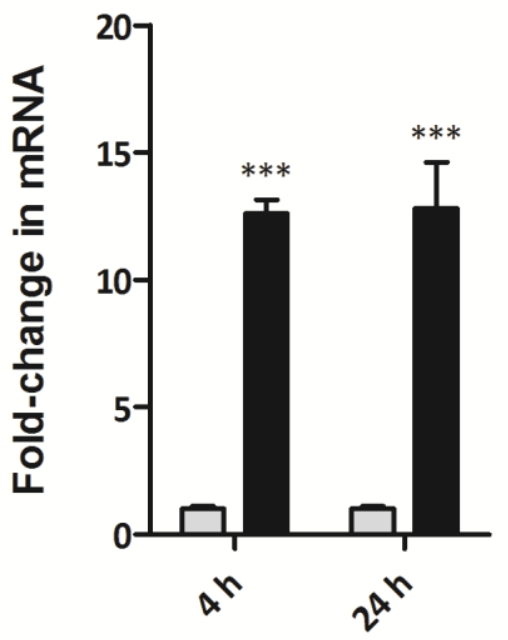

Incubation time 
Figure 2

COL11A1

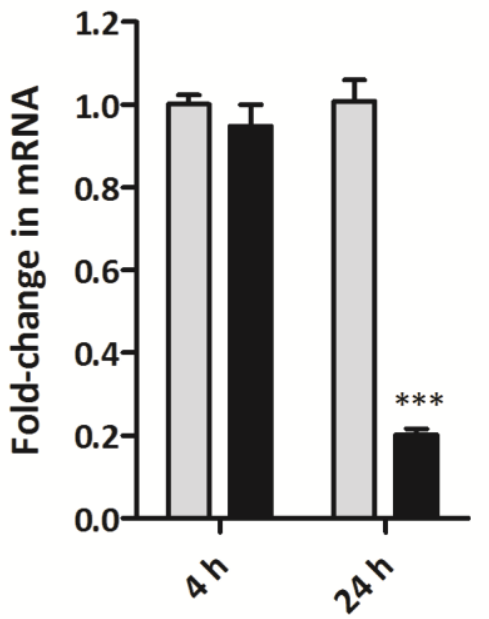

Incubation time

MMP16

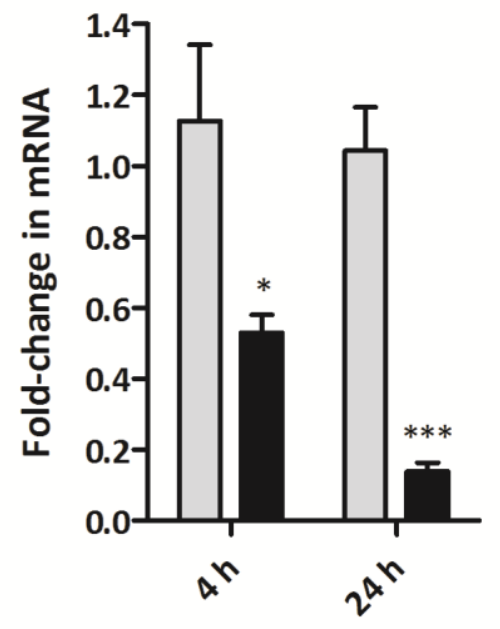

Incubation time
ITGA4

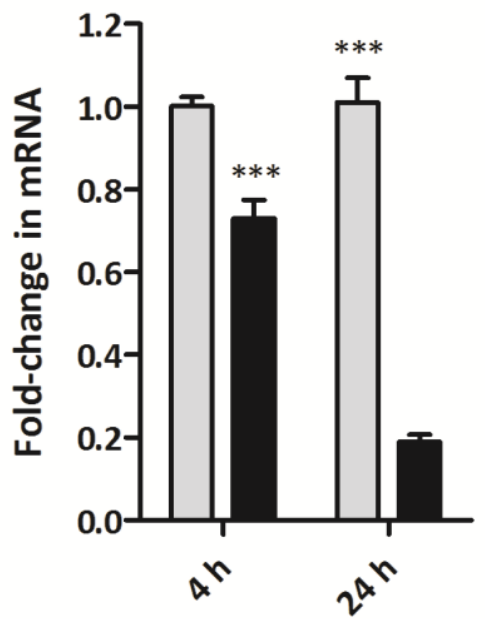

Incubation time

COL14A1

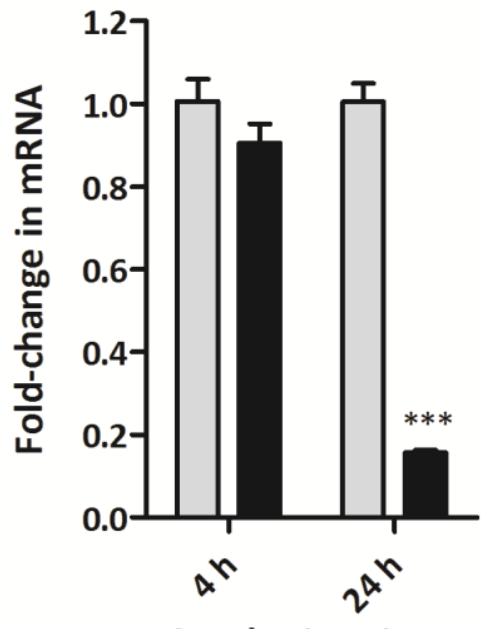

Incubation time 
Figure 3

ICAM-1
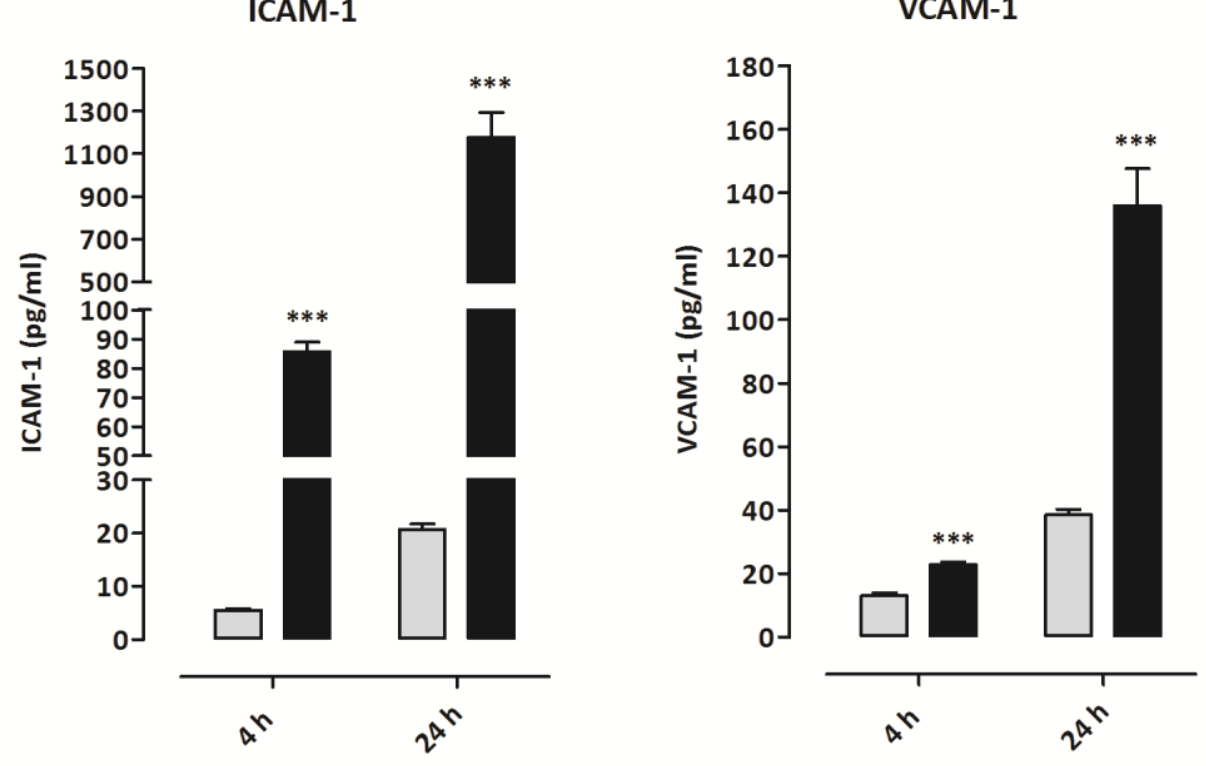

MMP-1
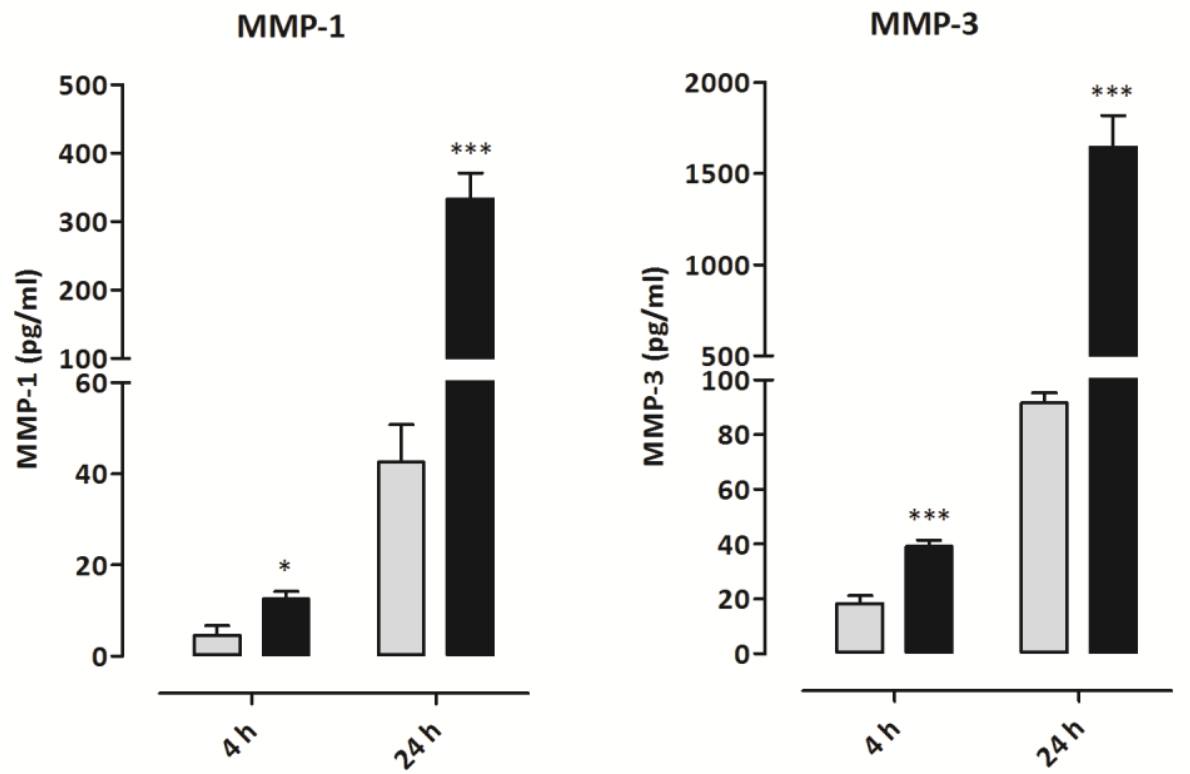


\section{Annex: Acceptance Information}

$12-$ oct -2016

Dear Professor Trayhurn:

Ref: PCR arrays indicate that the expression of extracellular matrix and cell adhesion genes in human adipocytes is regulated by IL-1 $\beta$ (interleukin$1 \beta)$

Our referees have now considered your paper and have recommended publication in Archives of Physiology And Biochemistry. We are pleased to accept your paper in its current form which will now be forwarded to the publisher for copy editing and typesetting. The reviewer comments are included at the bottom of this letter.

You will receive proofs for checking, and instructions for transfer of copyright in due course.

The publisher also requests that proofs are checked and returned within 48 hours of receipt.

Thank you for your contribution to Archives of Physiology And Biochemistry and we look forward to receiving further submissions from you.

Sincerely,

Dr Eckel

Editor in Chief, Archives of Physiology And Biochemistry

eckel@uni-duesseldorf.de 